\title{
Effects of diet on sinking rates and erosion thresholds of mussel Perna canaliculus biodeposits
}

\author{
Hilke Giles*, Conrad A. Pilditch \\ Department of Biological Sciences, University of Waikato, Private Bag 3105, Hamilton, New Zealand
}

\begin{abstract}
Suspension-feeding bivalves produce biodeposits (faeces and pseudofaeces) that have much higher sinking velocities than their constituent particles. Consequently, they cause sedimentation and redistribution of material that might otherwise not be deposited, enhancing the benthic-pelagic coupling of nearshore ecosystems. We quantified the dispersal characteristics (sinking velocity and erosion threshold) of biodeposits produced by the mussel Perna canaliculus, a species with high natural abundance that is also intensively cultured in New Zealand. We examined biodeposits produced by mussels of a wide size range (27 to $114 \mathrm{~mm}$ shell length) fed 3 diets (natural [N], algae [A] and silt [S] dominated) in the laboratory. Larger mussels produced bigger biodeposits that sank more quickly, and highly significant relationships between biodeposit size (faecal pellet width and pseudofaeces area) and sinking velocity were derived for each diet $\left(\mathrm{r}^{2}=0.43\right.$ to 0.79$)$. Biodeposit sinking velocities also varied significantly with diet. Mean sinking velocities of faecal pellets produced on the A diet $\left(0.67 \mathrm{~cm} \mathrm{~s}^{-1}\right)$ were approximately $4 \times$ lower than those of pellets produced on the $\mathrm{N}$ and S diets (2.46 to $2.71 \mathrm{~cm} \mathrm{~s}^{-1}$ respectively). Pseudofaeces produced on the $\mathrm{N}$ and A diets settled 50 to $70 \%$ slower than faeces produced on the same diet, but sinking velocities of S diet faeces and pseudofaeces were similar. In situ estimates of biodeposit sinking velocities measured in the Firth of Thames, New Zealand, were comparable to those produced on the N diet. Erosion thresholds were also affected by diet but not by mussel size. Ninety percent of faecal pellets produced on the A diet eroded at a bed shear velocity $\left(u^{*}\right)$ of $0.28 \mathrm{~cm} \mathrm{~s}^{-1}$, half that required to erode the same percentage of faecal pellets produced on the $\mathrm{N}$ and $\mathrm{S}$ diets. Pseudofaeces generally eroded over a similar but wider range of $u^{*}$, and the differences between the 3 diets were less distinctive than for faecal pellets. These results emphasise that mussel biodeposit dispersal (and hence the flux to the benthos) depends on the available diet and mussel size and thus could differ significantly between locations, seasons and the size structure of the population.
\end{abstract}

KEY WORDS: Faeces $\cdot$ Pseudofaeces $\cdot$ Dispersal $\cdot$ Benthic-pelagic coupling $\cdot$ Diet $\cdot$ Erosion $\cdot$ Sinking velocity $\cdot$ Bivalve

\section{INTRODUCTION}

Suspension-feeding bivalves, such as mussels, live as benthos within nearshore environments and play an important role in the coupling of pelagic and benthic ecosystems (e.g. Kautsky \& Evans 1987, Loo \& Rosenberg 1989, Dame 1993). They filter particles from the water column that are either rejected as pseudofaeces or ingested and subsequently egested as faeces
(Griffiths \& Griffiths 1987). Because the egested faeces and pseudofaeces (biodeposits) are compacted aggregates of particles in the water column, their sinking rates can be much greater than the rates of their constituent particles (Haven \& Morales-Alamo 1968, McCall 1979). Upon reaching the sediment surface, bottom currents can initiate the erosion of the biodeposits, leading to redistribution. Thus, a by-product of suspension-feeding is increased sedimentation and 
redistribution of particles that might otherwise not be deposited, leading to changes in the textural and chemical characteristics of the existing sediments as well as variations in the benthic community structure (Haven \& Morales-Alamo 1968, Dahlbaeck \& Gunnarsson 1981, Kaspar et al. 1985, Mirto et al. 2000, Norkko et al. 2001). Even though biodeposits are often very abundant, represent a repackaging of available organic matter and are readily transported, many contemporary studies continue to focus on the top-down effect of suspension-feeders on phytoplankton dynamics and much less attention has been paid to the role of biodeposits (Wotton \& Malmqvist 2001).

The extent to which biodeposits modify the existing sediments and affect benthic communities depends on their quality and quantity, the physical and chemical characteristics of the existing sediments, the composition of the benthos and hydrodynamic conditions. Biodeposits of suspension-feeding bivalves can be rich in carbon and nitrogen (Kautsky \& Evans 1987), and C:N ratios between 4.8 and 8.5 (Stuart et al. 1982, Kautsky \& Evans 1987, Loo \& Rosenberg 1989, Ahn 1993, Miller et al. 2002) suggest a high nutritional value (Parsons et al. 1984), indicating that biodeposits may represent a significant proportion of the energy potentially available to the benthos (Johannes \& Satomi 1966, Tenore et al. 1982). The nutritional value of biodeposits is dependent on diet (Butler \& Dam 1994, Miller et al. 2002). The natural diet of bivalves may include a variety of organic and inorganic components, and the composition of the food may vary widely in space and time (e.g. Fegley et al. 1992, Bayne 1993). Tidal currents and storm conditions can periodically resuspend the sediments in mussel habitats, increasing the silt proportion of the diet (Falconer \& Owens 1990, Sobral \& Widdows 2000), and algae blooms can lead to an organic enrichment of the ingested material.

In most coastal marine systems the flux of organic matter to the sediment significantly increases benthic productivity (Nixon 1981, Grall \& Chauvaud 2002) and affects primary production by supplying regenerated nutrients to the overlying water (Hargrave 1973). Faeces and pseudofaeces are characterised by a large bioavailability to microbial assemblages as well as rapid degradation rates (Grenz et al. 1990, Fabiano et al. 1994, La Rosa et al. 2002), and the mineralisation of biodeposits in the sediment causes higher nutrient release rates compared to sediments devoid of biodeposits (Asmus \& Asmus 1992, Dame 1993, Smaal \& Prins 1993, Newell et al. 2002). Where mussel beds are located in a well-mixed or the trophogenic zone of a stratified ecosystem, nutrients regenerated by the mussels and biodeposits are immediately available to primary producers (Nixon 1981, Kautsky \& Evans 1987). Besides their significant role in coupling the pelagic and benthic compartments of coastal ecosystems and their function as a food resource, biodeposits can also be utilised by animals for constructing tubes and similar structures (Wotton \& Malmqvist 2001).

Depending on the prevailing currents, biodeposits can be dispersed horizontally while sinking through the water column. In regions of high current velocities, biodeposits will be spread over a large area, reducing the flux to the benthos, whereas in low-energy environments biodeposits may accumulate at a greater rate. Thus the extent of their impact on sediment properties and the benthos is likely to vary greatly between these systems. Biodeposits can also be redistributed over a large area because they are more easily eroded than the surrounding sediments (Nowell et al. 1981, Minoura \& Osaka 1992, Roditi et al. 1997, Widdows et al. 1998, Austen et al. 1999). Few studies have examined the quantitative effects of faecal pellets produced by benthic organisms on particle fluxes (Graf \& Rosenberg 1997) and measured bed shear velocities required to erode biodeposits (Minoura \& Osaka 1992, Widdows et al. 1998, Austen et al. 1999, Andersen 2001). To predict the dispersal of biodeposits and hence their flux to the benthos, we quantified the sinking velocities and erosion thresholds of biodeposits produced by the common mussel Perna canaliculus.

The green-lipped mussel Perna canaliculus is endemic to New Zealand and found in a variety of habitats, attached to rock faces, wharf piles, among algal holdfasts in the intertidal zone and in deeper water over mud or sand (Morton \& Miller 1973). Mussels typically grow 100 to $170 \mathrm{~mm}$ long and are widely distributed throughout the country. P. canaliculus is also intensively cultured, and the extremely rapid growth of the aquaculture production of this species has led to constraints on further expansion (Jeffs et al. 1999). Because of the high natural abundance and intensive cultivation of $P$. canaliculus in New Zealand's nearshore ecosystems, it is important to understand the spatial extent of their biodeposit dispersal. A recent review of the use of ecosystem models for managing environmental impacts of mussel culture concluded that the key areas of modelling uncertainty include the parameterisation of biodeposit settling velocities, quality and erosion characteristics (Henderson et al. 2001). As a first step toward analysing the spatial dispersal of biodeposits and potential effects of mussel farms on the benthos, we measured sinking velocities and erosion thresholds of faeces and pseudofaeces produced by Perna canaliculus. Mussels of a wide size range were fed 3 experimental diets under controlled laboratory conditions to examine the influence of animal size and diet on biodeposit dispersal characteristics. In addition, in situ biodeposit sinking velocities were measured on 2 separate occasions. 


\section{MATERIALS AND METHODS}

Biodeposit production. Rope-cultured Perna canaliculus were collected by SCUBA divers from a commercial mussel farm in the Firth of Thames, New Zealand $\left(175^{\circ} 17^{\prime} \mathrm{E}, 36^{\circ} 59^{\prime} \mathrm{S}\right)$, a historic site of large mussel beds (Greenway 1969). Mussels were scraped clear of epibionts, transported to the laboratory and allowed to acclimatise to laboratory conditions for $8 \mathrm{~d}$ before exposure to the experimental diet in an aerated recirculating seawater system at $17 \pm 2^{\circ} \mathrm{C}$ on a $12 \mathrm{~h}$ light:12 $\mathrm{h}$ dark cycle. During this time no food was added to the system and mussels completely emptied their guts. Mussels were divided into 5 size classes (1: $<40 \mathrm{~mm}, 2: 41$ to $60 \mathrm{~mm}, 3: 61$ to $80 \mathrm{~mm}, 4: 81$ to $100 \mathrm{~mm}$ and 5: >100 mm shell length). Three mussels of the smallest 2 size classes and 2 mussels of each remaining size class were randomly selected from the acclimatised animals for exposure to the experimental diet and biodeposit production.

To examine the effects of diet on biodeposit dispersal characteristics, mussels were fed 3 experimental diets composed of natural seawater $(\mathrm{N}$ diet) and filtered $(5 \mu \mathrm{m})$ seawater mixed with either cultured algae (A diet) or silt (S diet; see Table 1). The amounts of algae and silt added were chosen to represent situations such as dense algae blooms that occur in shallow or unmixed eutrophic waters and high concentrations of silt caused by resuspension of sediments or riverine input in coastal ecosystems (Hawkins et al. 1999). The natural seawater was collected from Raglan, New Zealand $\left(174^{\circ} 57^{\prime} \mathrm{E}, 37^{\circ} 48^{\prime} \mathrm{S}\right)$, and used within $2 \mathrm{~d}$ of collection. The A diet was composed of $4.2 \mathrm{ml}$ of the cultured flagellate Isochrysis galbana per litre of filtered $(5 \mu \mathrm{m})$ seawater. For the $\mathrm{S}$ diet, sediment was collected from intertidal mud banks near the mussel farm, it was sieved $\left(<63 \mu \mathrm{m}_{\text {; }}\right.$ median grain size $\left.=17.2 \mu \mathrm{m}\right)$ and $1.1 \mathrm{ml}$ of the slurry was added per litre of filtered seawater.

Biodeposits were produced by exposing mussels contained in 8 flow-through feeding chambers (length $=15.5 \mathrm{~cm}$, width $=13 \mathrm{~cm}$, volume $=1.4 \mathrm{l})$ to the experimental diets. For the larger size classes ( 3 to $5 ; \mathrm{n}=2$ mussels per size class) a single mussel was placed in a feeding chamber, but for the smaller size classes (1 and 2 ) there were 3 mussels per chamber and size class. A header tank supplied the chambers with diet at a flow rate of $200 \mathrm{ml} \mathrm{min}^{-1}$, which was fast enough to prevent depletion within the chamber (Bayne 1993, Hawkins et al. 1996, 1998). Water leaving the chambers was collected and pumped back into the header tank for the A and $\mathrm{S}$ diets. Water samples were taken from the header tank at the start of each experiment and from the collection tank approximately every $\mathrm{h}$ thereafter for the analysis of suspended particulate material (S diet,
Hach DR/890 colorimeter) and in vivo fluorescence (A diet, Turner Designs 10-AU Fluorometer). If necessary more algae or silt-slurry was added to ensure consistent experimental conditions. For the $\mathrm{N}$ diet experiments, only fresh seawater was used; it was discarded once it had passed through the chambers. All biodeposit production experiments were conducted at $16 \pm$ $1^{\circ} \mathrm{C}$ and a salinity of $31.5 \pm 0.5 \mathrm{ppt}$. Four water samples for diet analysis were taken from the header tank during the biodeposit production period.

Mussels were allowed to acclimatise in the feeding chambers for $1 \mathrm{~h}$ before the start of the experiment (Hawkins et al. 1999). All biodeposits produced during the acclimatisation period were removed with pipettes without disturbing the animals. Pseudofaeces were fragile but stayed intact in the feeding chambers and when handled with care. Occasionally, pseudofaeces were damaged during handling, but these were discarded from further analysis. During the feeding experiment biodeposits were removed from the chambers approximately every $h$ until the end of the experiment (after 3.25 to $7 \mathrm{~h}$ ). For the sinking velocity measurements, biodeposits from each mussel were individually placed into vials filled with filtered seawater and photographed immediately under a Leica MZ12 microscope. From the digital images, biodeposit length, cross-sectional width and cross-sectional area were measured using image-analysis software (ImagePro Plus V. 4.5.1.22). For the erosion threshold measurements, only biodeposits produced by mussels of size classes 1, 3 and 5 were used, which captured the size range of biodeposits produced by all size classes. Biodeposits were kept in the dark and on ice in filtered seawater until the start of the erosion measurements (within $4 \mathrm{~h}$ ). Additional biodeposits were collected during the feeding experiments for analysis of their composition.

Biodeposit sinking velocities and erosion thresholds. Biodeposit sinking velocities were determined by timing the rate of descent of individual faecal pellets and pseudofaeces in a temperature-controlled settling tank (height $=2 \mathrm{~m}$, ID $=19 \mathrm{~cm}$ ) filled with filtered $(1.2 \mu \mathrm{m})$ seawater (temperature $[T]=18.4$ to $18.7^{\circ} \mathrm{C}$, salinity $[S]=31.2$ to $31.5 \mathrm{ppt}$ ). The temperature was controlled by pumping tap water through an outer column surrounding the tank for $24 \mathrm{~h}$ prior to and during the measurements. Preliminary experiments have shown that this reduces the spatial temperature variation in the tank (top, middle and lower sections) to $0.08^{\circ} \mathrm{C}$ and the variation over a $10 \mathrm{~h}$ period (maximum duration of measurements) to $0.25^{\circ} \mathrm{C}$. Biodeposits were transferred into the settling tank using a pipette and released approximately $1 \mathrm{~cm}$ below the water surface. They were allowed to sink untimed for $30 \mathrm{~cm}$ to eliminate momentum due to release, then the time taken to 
fall 3 consecutive $30 \mathrm{~cm}$ distances was recorded. For all analyses an average of these 3 readings was used. Sinking-velocity measurements of biodeposits coming within $3 \mathrm{~cm}$ of the sidewall were discarded.

Biodeposit erosion thresholds (here defined as the bed shear velocity required to initiate transport) were determined in a recirculating flume $(7.23 \mathrm{~m}$ long, $50 \mathrm{~cm}$ wide), described by Miller et al. (2002), that was filled to $15 \mathrm{~cm}$ with filtered $(5 \mu \mathrm{m})$ seawater $(T=19 \pm$ $1^{\circ} \mathrm{C}, S=31.5 \mathrm{ppt}$ ). Located in the working section of the flume, $5.5 \mathrm{~m}$ downstream of the entrance, were 2 core inserts, whose centres were located $20 \mathrm{~cm}$ from the side walls. Sediment cores (ID $=5.2 \mathrm{~cm}$ ) were placed into the inserts, ensuring that the sediment surface was flush with the flume floor. Sediment for the cores was collected from a mid-intertidal sandflat, prepared by wet-sieving through a $500 \mu \mathrm{m}$ mesh (median grain size $=33.7 \mu \mathrm{m})$, to remove macrofauna, and frozen until use.

Erosion thresholds were measured separately for biodeposits produced by mussels of size classes 1, 3 and 5 for each diet. Fifty freshly collected faecal pellets were placed onto 1 sediment core by letting them sink through a tube of the same diameter as the sediment core, and approximately 50 pseudofaeces were placed onto the second core. By arranging the biodeposits this way, we tried to simulate the natural distribution of biodeposits on the sediment surface. The flume motor speed was increased by $2 \mathrm{~Hz}$ every $10 \mathrm{~min}$, and the number of faecal pellets eroded off the sediment cores recorded. Pseudofaeces partly broke up when exposed to the flow, resulting in an almost even coverage of the sediment core area. Therefore, the percentage of the core area exposed was estimated after each incremental increase in flow speed. These measurements were conducted once for each of the 3 mussel size classes.

To convert flume motor output to estimates of bed shear velocity $\left(u^{*}, \mathrm{~cm} \mathrm{~s}^{-1}\right)$, velocity profiles were measured at the centre of the cores using a Sontek $10 \mathrm{MHz}$ Acoustic Doppler Velocimeter (ADV) for the range of motor settings used during the erosion measurements. Flow profiles started $0.8 \mathrm{~cm}$ above the bed to ensure that the bed is not included within the sampling volume (Finelli et al. 1999), and measurements were made at 9 additional heights $(z=1,1.5,2,2.5,3,4,5,6$ and $7 \mathrm{~cm})$. For each motor setting $(4,8,12,16$ and $20 \mathrm{~Hz}$ ) flow velocities were measured for $60 \mathrm{~s}$ at each height. Flow profiles were generated for both cores and shear velocities derived from the regression of velocity and log-transformed height above the sediment $\left(r^{2}=0.95\right.$ to 0.97$)$. No significant differences were found between the slopes or intercepts for the 2 cores ( $t$-test, $\mathrm{p}>0.05)$, so one common regression equation was calculated $\left(u^{*}\left[\mathrm{~cm} \mathrm{~s}^{-1}\right]=0.0234+0.0343 \times \mathrm{Hz}, \mathrm{r}^{2}=\right.$ 0.98, $\mathrm{p}<0.0005)$.
Biodeposit and diet analysis. Biodeposit and diet samples were processed the same day they were collected. Unless specified, duplicate samples were analysed, and prior to sub-sampling biodeposits were homogenised by vigorous shaking in filtered $(1.2 \mu \mathrm{m})$ seawater. For the determination of organic content (OC, \%) approximately 30 biodeposits were filtered onto ashed and pre-weighed $25 \mathrm{~mm}$ Whatman GF/C filters, rinsed with $20 \mathrm{ml}$ distilled water to remove salts, dried at $60^{\circ} \mathrm{C}$ for $24 \mathrm{~h}$ and ashed at $450^{\circ} \mathrm{C}$ for $4 \mathrm{~h}$. Suspended particulate material (SPM, $\mathrm{mg} \mathrm{l}^{-1}$ ) concentration, particulate organic matter (POM, mg $\mathrm{l}^{-1}$ ) concentration and $\mathrm{OC}$ of the diet samples were measured by filtering $500 \mathrm{ml}$ onto ashed and pre-weighed $47 \mathrm{~mm}$ Whatman GF/C filters, which were treated as described above for biodeposits. Chlorophyll a (chl a) and phaeopigment (Phaeo) content of biodeposits ( $\mu \mathrm{g} \mathrm{mg}$ $\mathrm{dw}^{-1}$ ) and diet $\left(\mu \mathrm{g}^{-1}\right.$ ) samples were determined by filtering 30 biodeposits or $100 \mathrm{ml}$ water, respectively, onto $25 \mathrm{~mm}$ Whatman GF/C filters that were frozen for $<6$ wk until analysis using the $90 \%$ acetone extraction method on a Turner Designs 10-AU Fluorometer (Arar $\&$ Collins 1997). For analysis of particulate carbon (PC,

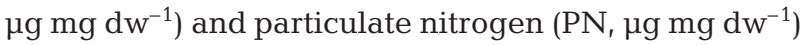
content, faecal pellets and pseudofaeces were rinsed with distilled water and dried at $60^{\circ} \mathrm{C}$ for $24 \mathrm{~h}$. Water samples were filtered onto $25 \mathrm{~mm}$ Whatman GF/C filters and analysed the same way for PC $\left(\mu \mathrm{g} \mathrm{l}^{-1}\right)$ and PN $\left(\mu \mathrm{g}^{-1}\right)$ concentration. PC and PN analyses were done using a Europa Scientific 20/20 isotope analyser.

Field measurements of biodeposit sinking velocities. Biodeposit sinking velocities were measured on 2 separate occasions in summer at the Firth of Thames mussel farm. A video camera and a cylindrical sediment trap (aspect ratio $=8.3$, height $=58 \mathrm{~cm}$ ) were attached to a frame; the camera recorded the lower section of the trap, in which a grid was placed. Biodeposits captured in the trap sank past the grid, and sinking velocities were derived from the time it took an individual biodeposit to travel the recorded distance. The frame holding the camera and sediment trap was set up approximately $2 \mathrm{~m}$ off the bottom. On the first occasion baffles were used to diminish turbulence and to create a calm layer in the trap allowing sinkingvelocity measurements (Bloesch \& Burns 1980). When analysing the video footage of these measurements, we noticed that pseudofaeces were absent. To ensure that pseudofaeces entered the trap, we repeated the experiment attaching a funnel covered by a mesh to the sediment trap and placed mussels onto the mesh so that biodeposits produced by the mussels descended directly into the trap.

All collected biodeposits were visually examined to ensure that they were Perna canaliculus biodeposits. On both occasions only mussel biodeposits were col- 
lected. Pseudofaeces area was determined by image analysis of the videographed pseudofaeces. Faecal pellet width could not be reliably determined from the video because of the pellets' orientation while settling. Instead, faecal pellets were collected from the sediment trap material and their width analysed as described above for biodeposits produced in the laboratory. This precluded assigning a width to each measured sinking velocity, and the average width of all captured faecal pellets was calculated instead. Water samples were taken and analysed as described above to compare the in situ diet composition (SPM, POM, OC, chl $a$ and Phaeo) to the laboratory diets (Table 1).

Statistical analysis. We fitted general linear models (GLMs) to determine the relationships between biodeposit size (faecal pellet width and pseudofaeces area) and mussel size class and experimental diet using GenStat (V. 6.1.0.200, (C) 2002 Lawes Agricultural Trust). We performed Tukey post-hoc tests using MINITAB $^{\text {TM }}$ (Release 13.32) to investigate the difference between individual treatments for significant GLM results $(\alpha=0.05)$. GLMs were also fitted to biodeposit sinking velocity with factors biodeposit size, mussel size class and experimental diet. We conducted additional multiple comparison tests ( $t$-test, GenStat) to examine differences between slopes and intercepts. Sinking velocity and biodeposit morphometric data (faecal pellet width and pseudofaeces area) were $\log _{10}$ transformed to satisfy the assumptions of homogeneity of variance and normality. We used GLMs because they allow categorical variables as predictors (such as mussel size class and experimental diet) and do not assume slopes of fitted lines to be equal. To quantify the relationship between sinking velocity and biodeposit size, linear regression analyses were conducted for faecal pellets and pseudofaeces using MINITAB ${ }^{\mathrm{TM}}$. Although we could assign each biodeposit to the individual mussel that produced them, preliminary analysis indicated that the variation in the size of biodeposits produced by a single individual was greater than the variation between individual mussels of the same size class. We therefore treated each biodeposit as a replicate for statistical analyses.

\section{RESULTS \\ Diets}

The characteristics of the 3 experimental diets were very different (Table 1). The $\mathrm{N}$ diet had a SPM concentration of $20.9 \mathrm{mg} \mathrm{l}^{-1}$, OC of $12.3 \%$ and a chl a concentration of $2.56 \mu \mathrm{g} \mathrm{l}^{-1}$. The A diet was characterised by a very high chl a concentration $\left(578 \mu \mathrm{g} \mathrm{l}^{-1}\right)$ and $\mathrm{OC}$ of $70.2 \%$. On the other hand, the S diet had a $5 \times$ higher SPM concentration compared with the $\mathrm{N}$ diet but similar OC and chl a concentration, possibly a result of microphytobenthos and/or sediment bacteria. PC and PN concentrations were highest for the A diet, followed by the $\mathrm{S}$ and $\mathrm{N}$ diets. The $\mathrm{C}: \mathrm{N}$ ratio of the A diet was 6.7 and increased for the $\mathrm{S}(7.4)$ and $N$ diets (8.5). The in situ diets were most similar to the $\mathrm{N}$ diet but on both occasions had lower SPM concentrations and higher OC (Table 1).

\section{Biodeposit shape and composition}

Mussels produced pseudofaeces within a few minutes of being placed into the feeding chambers and faeces after approximately $30 \mathrm{~min}$. Faecal pellet production rates differed among the 3 diets so to ensure sufficient pellets for analysis, feeding time varied between $3.25 \mathrm{~h}$ for the $\mathrm{N}$ diet to $7 \mathrm{~h}$ for the A diet. However, despite the extended duration of the A diet treatment mussels produced only 79 pellets, compared with 174 on the $\mathrm{N}$ and 192 on the S diet.

Table 1. Summary of experimental (N: natural, A: algae, S: silt) and in situ (Field) diet characteristics. Data are the treatment means of water samples collected during biodeposit production $(\mathrm{n}=2$ to 4 ) and in situ (Field 1: $\mathrm{n}=10$, Field 2: $\mathrm{n}=4$ ). Standard deviations are given when more than 2 replicates were determined. Suspended particulate material (SPM), particulate organic matter (POM), organic content (OC), chlorophyll a (chl a), phaeopigment (Phaeo), particulate carbon and nitrogen (PC, PN) and $\mathrm{C}: \mathrm{N}$ ratio. $\mathrm{ND}=$ no data

\begin{tabular}{|lccccc|}
\hline & N diet & A diet & S diet & Field 1 & Field 2 \\
\hline SPM $\left(\mathrm{mg} \mathrm{l}^{-1}\right)$ & $20.9 \pm 8.1$ & $53.6 \pm 4.9$ & $101.5 \pm 15.4$ & $7.3 \pm 2.3$ & $5.6 \pm 0.7$ \\
POM $\left(\mathrm{mg} \mathrm{l}^{-1}\right)$ & $2.5 \pm 0.8$ & $37.1 \pm 5.1$ & $12.3 \pm 2.7$ & $2.1 \pm 0.5$ & $1.6 \pm 0.3$ \\
OC $(\%)$ & $12.3 \pm 4.1$ & $70.2 \pm 6.4$ & $12.2 \pm 2.4$ & $30.1 \pm 6.6$ & $29.0 \pm 4.0$ \\
Chl $a\left(\mu \mathrm{g} \mathrm{l}^{-1}\right)$ & $2.56 \pm 0.41$ & $578 \pm 39$ & $2.52 \pm 0.63$ & $2.07 \pm 0.60$ & $4.26 \pm 0.99$ \\
Phaeo $\left(\mu \mathrm{g} \mathrm{l}^{-1}\right)$ & $1.50 \pm 0.28$ & $26.1 \pm 1.3$ & $6.04 \pm 0.94$ & $0.91 \pm 0.21$ & $1.74 \pm 0.43$ \\
PC $\left(\mu \mathrm{g} \mathrm{l}^{-1}\right)$ & 827 & 14652 & 2814 & ND & ND \\
PN $\left(\mu \mathrm{g} \mathrm{l}^{-1}\right)$ & 98 & 2200 & 381 & ND & ND \\
C:N (by weight) & 8.5 & 6.7 & 7.4 & & ND \\
\hline
\end{tabular}


Faecal pellets had a cylindrical shape, but rather than being a closed cylinder, the edges curled up and rolled over inwards creating a longitudinal groove (Fig. 1a). Pellets produced on the $\mathrm{N}$ and $\mathrm{S}$ diets were light brown and had an even, slightly rough texture compared with those produced on the A diet, which were dark green with a soft, silky texture. Because of this distinctive shape it was not possible to measure the volume of faecal pellets produced by Perna canaliculus so pellet length, width and cross-sectional area were chosen as size parameters. Pseudofaeces were readily distinguished from faeces. They were amorphous in shape (Fig. 1b), consisting of a fluffy texture and colour identical to that of the faecal pellets. It was not possible to define volume, length or width of the pseudofaeces, and therefore cross-sectional area was used to describe their size.

The composition of biodeposits reflected the diets mussels were fed (Tables $1 \& 2$ ). Biodeposits produced on the A diet had an $~ 8 \times$ higher OC compared with those produced on the $\mathrm{N}$ and $\mathrm{S}$ diets, and values of faecal pellets and pseudofaeces were very similar. The chl a content was higher for pseudofaeces than faeces for all diets and $\sim 37 \times$ higher on the A diet compared with the $\mathrm{N}$ diet and $\sim 120 \times$ higher compared with the $\mathrm{S}$ diet. Phaeo concentrations were lower for pseudofaeces than faeces for the $\mathrm{N}$ and $\mathrm{S}$ diets but increased for the A diet. They were also much higher for biodeposits produced on the A diet $(\sim 72$ to $>600 \times)$ compared with

(a) Faecal pellet

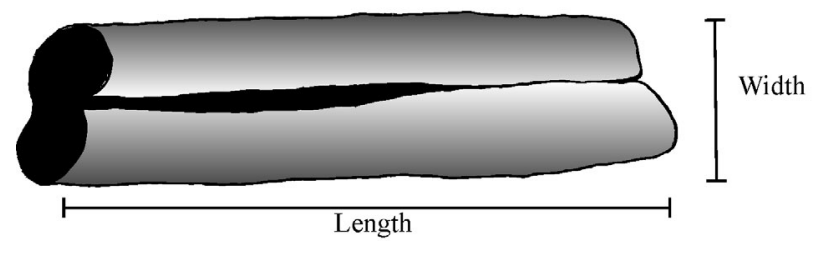

(b) Pseudofaeces

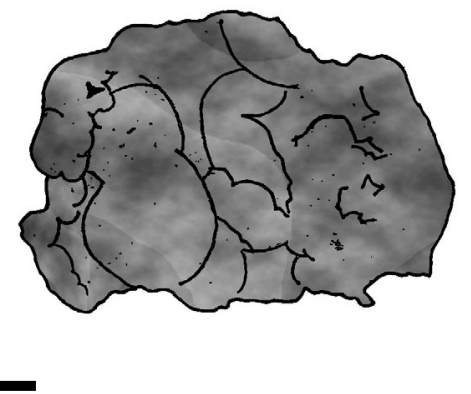

Fig. 1. Perna canaliculus. (a) faecal pellet and (b) pseudofaeces. Faecal pellets ranged in length from 1.0 to $65.2 \mathrm{~mm}$ and in width from 0.22 to $1.86 \mathrm{~mm}$, whereas pseudofaeces were between 0.6 and $10.0 \mathrm{~mm}^{2}$ in area
Table 2. Perna canaliculus. Summary of biodeposit characteristics (mean $\pm \mathrm{SD}, \mathrm{n}=4$ and for remainder $\mathrm{n}=2$ ) produced on the 3 experimental diets (N: natural, A: algae, S: silt)

\begin{tabular}{|c|c|c|}
\hline & Faeces & Pseudofaeces \\
\hline \multicolumn{3}{|c|}{ Organic content $(\%)$} \\
\hline $\mathrm{N}$ diet & $11.9 \pm 0.9$ & $9.6 \pm 0.3$ \\
\hline A diet & 93.8 & 93.4 \\
\hline S diet & $11.8 \pm 0.7$ & $12.1 \pm 2.2$ \\
\hline \multicolumn{3}{|c|}{ Chlorophyll a content $\left(\mu \mathrm{g} \mathrm{mg} \mathrm{dw^{-1 } )}\right.$} \\
\hline $\mathrm{N}$ diet & $0.10 \pm 0.03$ & $0.12 \pm 0.01$ \\
\hline A diet & 3.68 & 4.42 \\
\hline S diet & $0.033 \pm 0.004$ & $0.035 \pm 0.007$ \\
\hline \multicolumn{3}{|c|}{ Phaeopigment content ( $\mu \mathrm{g} \mathrm{mg} \mathrm{dw^{-1 } )}$} \\
\hline $\mathrm{N}$ diet & $0.167 \pm 0.04$ & $0.047 \pm 0.003$ \\
\hline A diet & 12 & 29 \\
\hline S diet & $0.087 \pm 0.02$ & $0.042 \pm 0.005$ \\
\hline \multicolumn{3}{|c|}{ Carbon content ( $\left.\mu \mathrm{g} \mathrm{mg} \mathrm{dw}^{-1}\right)$} \\
\hline $\mathrm{N}$ diet & 30.1 & 34.7 \\
\hline A diet & 287 & 392 \\
\hline S diet & 29.7 & 24.8 \\
\hline \multicolumn{3}{|c|}{ Nitrogen content ( $\left.\mu \mathrm{g} \mathrm{mg} \mathrm{dw} w^{-1}\right)$} \\
\hline $\mathrm{N}$ diet & 3.54 & 4.02 \\
\hline A diet & 40.1 & 59.9 \\
\hline S diet & 3.98 & 3.24 \\
\hline \multicolumn{3}{|c|}{ C:N (by weight) } \\
\hline $\mathrm{N}$ diet & 8.5 & 8.6 \\
\hline A diet & 7.2 & 6.6 \\
\hline S diet & 7.5 & 7.7 \\
\hline
\end{tabular}

the other 2 diets. The C:N ratio was higher for biodeposits produced on the $\mathrm{N}$ diet compared with those on the $\mathrm{S}$ and A diets (Table 2).

\section{Biodeposit size}

A correlation analysis of faecal pellet sinking velocity with pellet morphometrics (length, width and area) revealed that the best correlations (Pearson's correlation coefficient, r) occurred with width for all diets $(\mathrm{N}$ diet: $\mathrm{r}=0.85$; A diet: $\mathrm{r}=0.73$; $\mathrm{S}$ diet: $\mathrm{r}=0.74 ; \mathrm{p}<$ 0.0005). Correlations of pellet sinking velocity with length and area were also highly significant $(\mathrm{p}<$ 0.0005), but the correlation coefficients were reduced by 0.10 to 0.34 compared with width. Faecal pellet width was therefore chosen as the size description variable for the statistical analyses. The correlations between pseudofaeces sinking velocity and crosssectional area were also highly significant $(\mathrm{N}$ diet: $\mathrm{r}=$ 0.46 , A diet: $\mathrm{r}=0.75$, $\mathrm{S}$ diet: $\mathrm{r}=0.73$; $\mathrm{p}<0.0005$ ).

Larger mussels produced larger biodeposits (Table 3). The average width of faecal pellets produced on the $\mathrm{N}$ diet ranged from 0.54 (mussel size class 1 ) to 
Table 3. Perna canaliculus. Mean faecal pellet width $( \pm$ SD) and mean pseudofaeces area $( \pm$ SD) produced by mussels of different size classes (range of shell lengths given below size class, $\mathrm{mm}$ ) on the experimental diets (N: natural, A: algae, S: silt). Number of biodeposits measured is given in parentheses

\begin{tabular}{|c|c|c|c|c|c|}
\hline & $\begin{array}{c}1 \\
27.3-36.1\end{array}$ & $\begin{array}{c}2 \\
45.3-58.7\end{array}$ & $\begin{array}{c}\text { Mussel size class } \\
3 \\
63.2-78.7\end{array}$ & $\begin{array}{c}4 \\
84.5-95.6\end{array}$ & $\begin{array}{c}5 \\
101.0-114.1\end{array}$ \\
\hline \multicolumn{6}{|c|}{ Faecal pellet width (mm) } \\
\hline $\mathrm{N}$ diet & $0.54 \pm 0.06$ & $0.85 \pm 0.07(31)$ & $1.07 \pm 0.12(38)$ & $1.37 \pm 0.16(38)$ & $1.49 \pm 0.19(33)$ \\
\hline A diet & $0.42 \pm 0.12$ & $0.87 \pm 0.29$ & $0.98 \pm 0.14$ & $1.27 \pm 0.30(17)$ & $1.29 \pm 0.34$ \\
\hline $\mathrm{S}$ diet & $0.50 \pm 0.07$ & $0.76 \pm 0.13$ & $0.99 \pm 0.14$ & $1.18 \pm 0.20(39)$ & $1.19 \pm 0.23(37)$ \\
\hline \multicolumn{6}{|c|}{ Pseudofaeces area $\left(\mathrm{mm}^{2}\right)$} \\
\hline $\mathrm{N}$ diet & $1.76 \pm 1.00(5)$ & $1.82 \pm 0.88(4)$ & $2.67 \pm 1.00(5)$ & $3.42 \pm 1.13(5)$ & $4.25 \pm 1.49(5)$ \\
\hline A diet & $1.31 \pm 0.76(5)$ & $2.65 \pm 0.78$ & $4.28 \pm 1.94(5)$ & $6.65 \pm 2.99$ & $7.13 \pm 3.11$ \\
\hline $\mathrm{S}$ diet & $1.74 \pm 0.43(5)$ & $2.45 \pm 0.47(5)$ & $5.57 \pm 1.65(5)$ & $4.90 \pm 1.41(5)$ & $5.50 \pm 1.31(5)$ \\
\hline
\end{tabular}

$1.49 \mathrm{~mm}$ (mussel size class 5). Pellets produced on the $\mathrm{S}$ diet were slightly narrower for all size classes, ranging from 0.50 to $1.19 \mathrm{~mm}$, and those produced on the A diet had widths between 0.42 and $1.29 \mathrm{~mm}$. Mean pseudofaeces area of mussels fed the $\mathrm{N}$ diet was $1.76 \mathrm{~mm}^{2}$ for size class 1 and increased to $4.25 \mathrm{~mm}^{2}$ for size class 5 . Those produced on the A diet had a greater disparity between small and large mussels, with mean pseudofaeces area ranging from 1.31 to $7.13 \mathrm{~mm}^{2}$. Average area of pseudofaeces produced on the $\mathrm{S}$ diet was $1.74 \mathrm{~mm}^{2}$ for size class 1 and $5.50 \mathrm{~mm}^{2}$ for size class 5. Pseudofaeces produced by mussels of size class 3 on the $\mathrm{S}$ diet were unusually large $\left(5.57 \mathrm{~mm}^{2}\right)$ compared with size classes 4 and 5 .

To analyse the effects of mussel size and diet on biodeposit size, we fitted GLMs to $\log _{10}$-transformed faecal pellet width and pseudofaeces area with mussel size class and diet as factors. The model of faecal pellet width indicated significant effects of mussel size class and diet $(\mathrm{p}<0.001)$ as well as a significant interaction term of the 2 factors ( $p<0.001$ ). It explained $80.8 \%$ of the variation $\left(\mathrm{r}^{2}\right)$ in faecal pellet width $(\mathrm{p}<0.001)$ and had a standard error (SE) of $0.0814(\mathrm{n}=445)$. The GLM of pseudofaeces area $\left(\mathrm{p}<0.001, \mathrm{r}^{2}=60.7 \%\right.$, SE $=0.176$, $\mathrm{n}=74$ ) also showed significant effects of mussel size class $(p<0.001)$ and diet $(p=0.005)$ on biodeposit size, but the interaction term did not contribute significantly to the explanation of the data $(p=0.210)$. Therefore, $a$ simpler model could be fitted, omitting the interaction term of mussel size class and diet. The simplified model explained $58.7 \%$ of the variation in pseudofaeces area $(p<0.001, S E=0.181)$ with significant effects of mussel size class $(p<0.001)$ and diet $(p=0.006)$.

To examine differences in faecal pellet width and pseudofaeces area among mussel size classes, we conducted multiple comparison tests for each diet (Tukey test, $\alpha=0.05)$. Faecal pellets produced by mussels of size class 1 were significantly smaller than those produced by larger mussels for all experimental diets
(Table 4). The difference between mean pellet width was significant for all mussel size classes fed the $\mathrm{N}$ diet and for those fed the $\mathrm{S}$ diet, only the difference between size classes 4 and 5 was non-significant. Faecal pellets produced on the A diet were not significantly different between size classes 2 and 3 as well as between size classes 3,4 and 5. Comparison of the mean pseudofaeces areas revealed that the distinction among size classes was not as great as for faecal pellets (Table 4). The only significant size difference of pseudofaeces produced on the $\mathrm{N}$ diet was between mussel size classes 1 and 5, and on the A diet significant differences were found between size classes 1 and 3 or higher as well as between size classes 2 and 5. Pseudofaeces area for mussels produced on the $\mathrm{S}$ diet were not significantly different between size classes 1 and 2 as well as between size classes 3, 4 and 5 .

Table 4. Perna canaliculus. Multiple comparisons of mean biodeposit sizes between mussel size classes for experimental diets (N: natural, A: algae, S: silt). Separate lines represent significant differences (Tukey test, $\mathrm{p}<0.05$ ), and where lines are joined no significant differences were observed

\begin{tabular}{|c|c|c|c|c|c|}
\hline & \multicolumn{5}{|c|}{ Mussel size class } \\
\hline & 1 & 2 & 3 & 4 & 5 \\
\hline \multicolumn{6}{|c|}{ Faecal pellet width } \\
\hline $\mathrm{N}$ diet & & - & - & 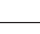 & - \\
\hline A diet & & 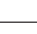 & 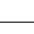 & & \\
\hline $\mathrm{S}$ diet & 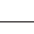 & - & - & 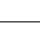 & - \\
\hline \multicolumn{6}{|c|}{ Pseudofaeces area } \\
\hline $\mathrm{N}$ diet & & & & _ & \\
\hline A diet & & 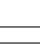 & & & \\
\hline $\mathrm{S}$ diet & & & & & \\
\hline
\end{tabular}




\section{Biodeposit sinking velocities}

Biodeposit sinking rates varied with diet and were generally lower for pseudofaeces compared to faeces (Figs. 2 \& 3). Sinking velocities of faecal pellets produced on the $\mathrm{N}$ diet ranged from 0.9 to $4.3 \mathrm{~cm} \mathrm{~s}^{-1}$, whereas the corresponding rates for pseudofaeces were only about half as large ( 0.5 to $\left.2.2 \mathrm{~cm} \mathrm{~s}^{-1}\right)$. Faecal pellets produced on the $\mathrm{S}$ diet had similar sinking velocities (1.1 to $4.5 \mathrm{~cm} \mathrm{~s}^{-1}$ ) to those on the $\mathrm{N}$ diet, and pseudofaeces sank equally fast (1.1 to $\left.4.0 \mathrm{~cm} \mathrm{~s}^{-1}\right)$. Both faeces and pseudofaeces produced on the A diet had much lower sinking velocities than those produced on the other 2 diets (faeces: 0.2 to $1.5 \mathrm{~cm} \mathrm{~s}^{-1}$, pseudofaeces: 0.1 to $0.8 \mathrm{~cm} \mathrm{~s}^{-1}$ ).

To examine how biodeposit sinking velocity was affected by diet, biodeposit size and mussel size class, we fitted GLMs to $\log _{10}$-transformed faecal pellet and pseudofaeces sinking velocities. In the GLM of faecal pellet sinking velocity, all 3 independent variables were significant $(p<0.001)$, but the order in which biodeposit size and mussel size class were fitted in the model determined which of these variables described the greater amount of variation in sinking velocity. We decided that faecal pellet width was the most important variable for the model, since it is commonly used to characterise biodeposit size, whereas mussel size class is a rather arbitrary definition. Furthermore, adding mussel size class to the model only explained an additional $3.1 \%$ of the variation in the data. These arguments and the close relationships of mussel size class and biodeposit size described above suggested that it was acceptable to omit mussel size class in favour of faecal pellet width in the model of faecal pellet sinking velocity.

The GLM explained $91 \%$ of the variation in faecal pellet sinking velocity $(\mathrm{p}<0.001, \mathrm{SE}=0.0873, \mathrm{n}=445)$. Faecal pellet width and diet had significant effects on sinking velocity $(\mathrm{p}<0.001)$, and the interaction between these 2 variables was also significant $(\mathrm{p}=$ 0.010). Further multiple comparison tests ( $t$-test, GenStat) showed significant differences between the slopes for the $\mathrm{N}$ and $\mathrm{S}$ diets $(\mathrm{p}=0.005)$ as well as the $\mathrm{A}$ and $\mathrm{S}$ diets $(\mathrm{p}=0.017)$, but no significant difference between the $\mathrm{N}$ and $\mathrm{A}$ diets $(\mathrm{p}=0.711)$. The intercepts of the regression lines for the $\mathrm{N}$ and $\mathrm{A}$ diets were significantly different $(p<0.001)$.

The GLM for pseudofaeces sinking velocity explained $88 \%$ of the variation in the data $(\mathrm{p}<0.001$, $\mathrm{SE}=0.124, \mathrm{n}=74)$ and revealed significant contributions of pseudofaeces area and diet $(p<0.001)$ but not mussel size class $(p=0.191)$. The interaction term of pseudofaeces area and diet was not significant $(p=$ 0.580 ), indicating equal slopes of sinking velocity versus pseudofaeces area for all 3 experimental diets. The
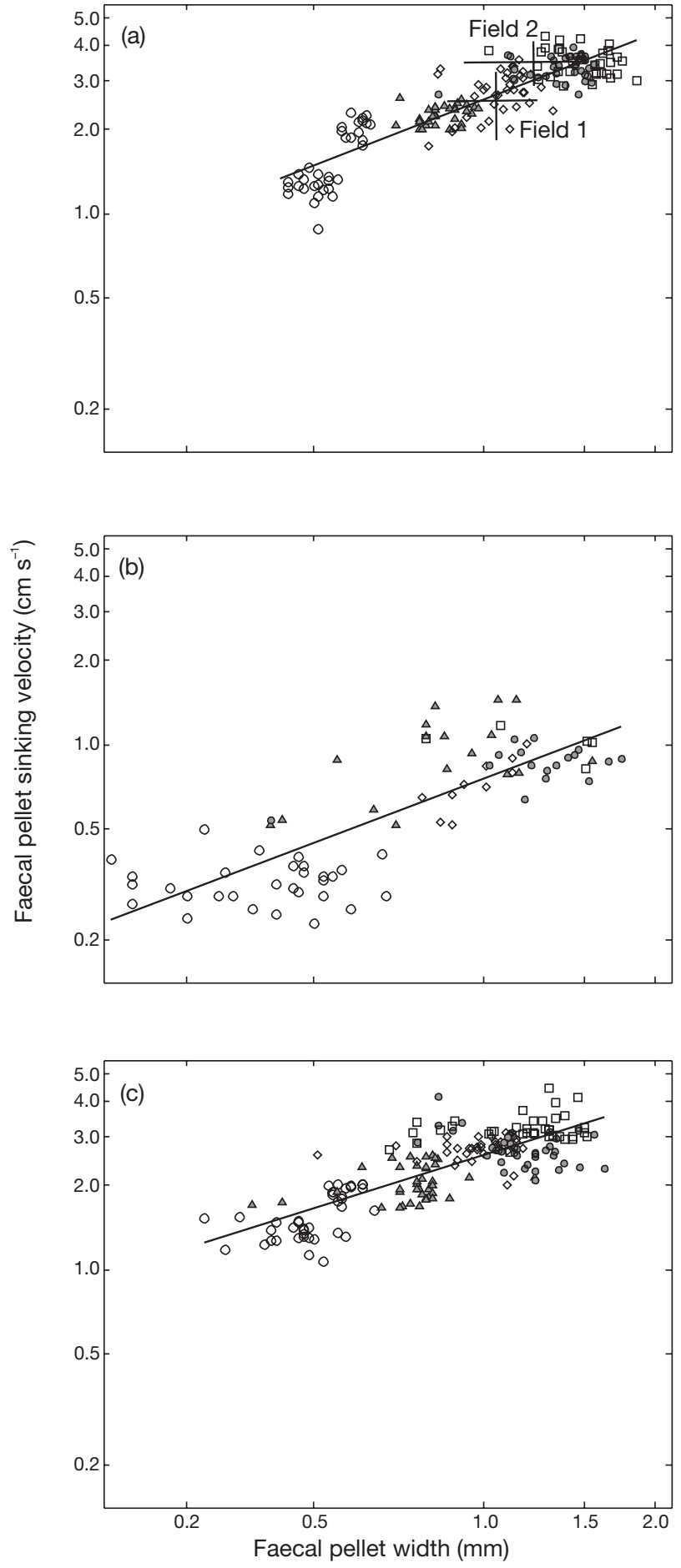

Fig. 2. Perna canaliculus. Relationship between faecal pellet sinking velocity and width for the experimental diets: (a) natural diet, (b) algae diet and (c) silt diet. Mussel size classes are indicated by symbols: $(0)<40 \mathrm{~mm},(\Delta) 41-60 \mathrm{~mm},(\diamond) 61-$ $80 \mathrm{~mm}$, ( ( ) $81-100 \mathrm{~mm}$ and (ㅁ) $>100 \mathrm{~mm}$ shell length. The crosses in (a) represent the mean \pm SD of width and sinking velocity of the 2 in situ measurements (Fields 1 and 2). Solid lines represent linear regression lines fitted to the data. Regression statistics are given in Table 5 

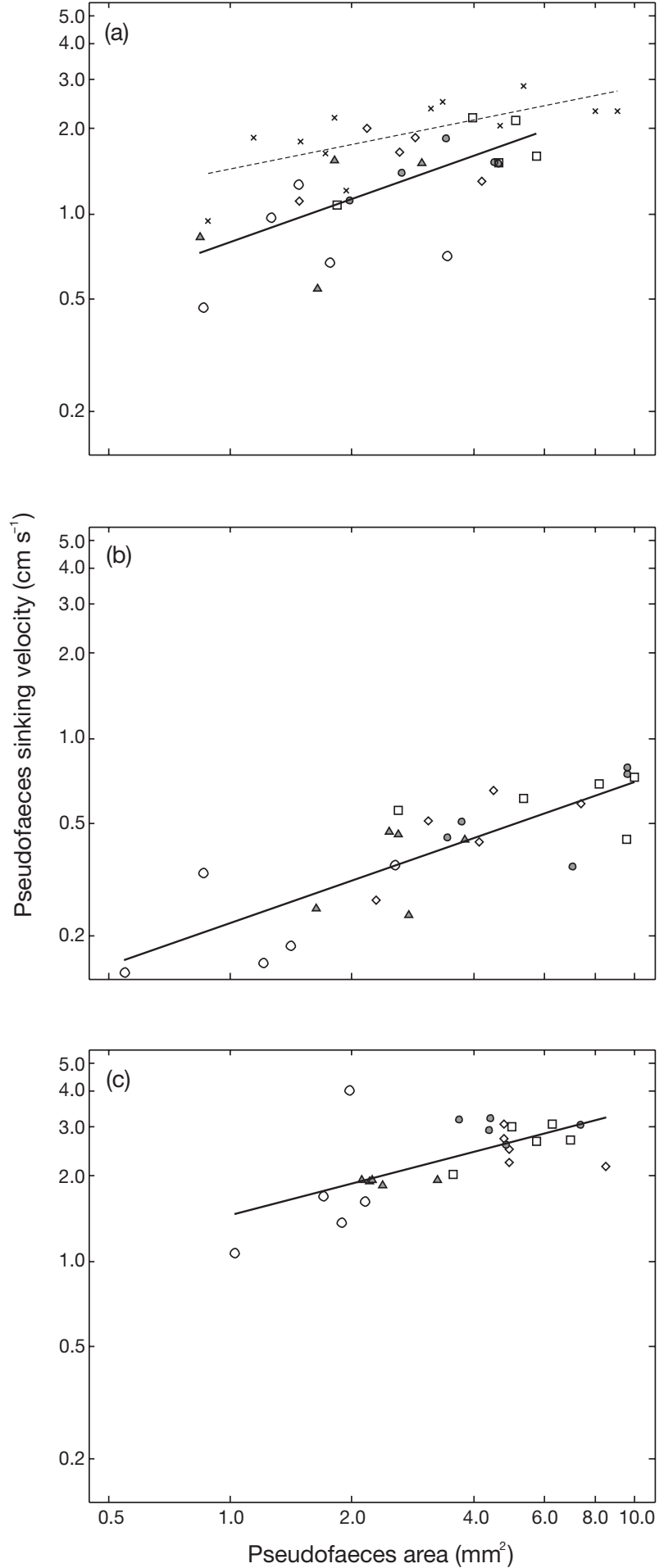

Fig. 3. Perna canaliculus. Relationship between pseudofaeces sinking velocity and area for the experimental diets. Experimental diets $(\mathrm{a}-\mathrm{C})$ and mussel size classes indicated by symbols as in Fig. 2. In situ pseudofaeces measurements are indicated by $(x)$ in (a). Solid lines represent linear regression lines fitted to the data. Dashed line in (a) represents a linear regression line fitted to the in situ measurements. Regression statistics are given in Table 5
GLM showed significant differences between the intercepts of all 3 regression lines ( $p<0.001)$, indicating significantly higher sinking velocities for pseudofaeces produced on the $\mathrm{S}$ diet and the lowest rates for those produced on the A diet.

To quantify the relationships between sinking velocity and biodeposit size (faecal pellet width and pseudofaeces area), a simple linear regression analysis was conducted (Table 5). All regressions were significant $(\mathrm{p}<0.0005)$, and regressions generally had stronger fits (i.e. higher coefficients of determination, $\left.r^{2}\right)$ for faecal pellets $\left(r^{2}=0.64\right.$ to 0.79$)$ than pseudofaeces $\left(r^{2}=0.43\right.$ to 0.66$)$. The amount of variation in biodeposit sinking velocity explained by biodeposit size was highest for faecal pellets produced on the $\mathrm{N}$ diet and pseudofaeces produced on the A diet.

The faecal pellet size and sinking velocities measured in situ on both occasions were well within the range of those produced in the laboratory under the natural diet (Fig. 2). During the time of our deployments, the mussels at the commercial farm were approximately 55 to $100 \mathrm{~mm}$ long and hence did not represent the very small $(<40 \mathrm{~mm})$ and very large ( $>100 \mathrm{~mm}$ ) mussels used in the laboratory measurements. This is illustrated by the lack of very small ( $<0.50 \mathrm{~mm}$ width) and very large (>1.79 mm width) faecal pellets collected in the sediment trap. The size range of pseudofaeces captured represented the complete range of pseudofaeces analysed in the laboratory (Fig. 3), and their sinking velocities (0.95 to $2.84 \mathrm{~cm} \mathrm{~s}^{-1}$ ) were most similar to those measured in the laboratory on the N diet. Sinking velocities also increased significantly with pseudofaeces size $\left(p=0.011, r^{2}=0.49\right.$; Table 5).

Table 5. Perna canaliculus. Linear regression analysis of biodeposit sinking velocity $\left(\mathrm{cm} \mathrm{s}^{-1}\right)$ vs biodeposit size for experimental (N: natural, A: algae, S: silt) and in situ diets. Faecal pellet sinking velocity $=a+b \times$ width $(\mathrm{mm})$ and pseudofaeces sinking velocity $=a+b \times$ area $\left(\mathrm{mm}^{2}\right)$. All data were $\log _{10}$ transformed before analysis

\begin{tabular}{|c|c|c|c|c|c|}
\hline & a & $b$ & $r^{2}$ & $\mathrm{p}$ & $\mathrm{n}$ \\
\hline \multicolumn{6}{|c|}{ Faecal pellets (sinking velocity vs width) } \\
\hline $\mathrm{N}$ diet & 0.410 & 0.789 & 0.79 & $<0.0005$ & 174 \\
\hline A diet & -0.120 & 0.769 & 0.65 & $<0.0005$ & 79 \\
\hline $\mathrm{S}$ diet & 0.412 & 0.632 & 0.64 & $<0.0005$ & 192 \\
\hline \multicolumn{6}{|c|}{ Pseudofaeces (sinking velocity vs area) } \\
\hline $\mathrm{N}$ diet & -0.099 & 0.504 & 0.43 & $<0.0005$ & 24 \\
\hline A diet & -0.650 & 0.501 & 0.66 & $<0.0005$ & 25 \\
\hline $\mathrm{S}$ diet & 0.163 & 0.370 & 0.43 & $<0.0005$ & 25 \\
\hline In situ & 0.157 & 0.291 & 0.49 & 0.011 & 12 \\
\hline
\end{tabular}




\section{Biodeposit erosion}

The erosion thresholds of faecal pellets produced by mussels of different size classes fed different diets were analysed by comparing the bed shear velocities $\left(u^{*}\right)$ required to erode 10,50 and $90 \%$ of the pellets. These $u^{*}$ were determined from logistic curves that describe the relationship between number of faecal pellets eroded and the bed shear velocity $\left(r^{2}=0.98\right.$ to 1.00$)$. Three of the 9 data sets could not be modelled by a logistic curve because most of the biodeposits eroded simultaneously. In these cases a straight line was fitted to describe the erosion phase. Be-cause pseudofaeces partly broke up during the measurements, we compared the $u *$ required to expose 10,50 and $90 \%$ of the area initially covered by pseudofaeces. Because the erosion measurements were only performed once, no statistical analysis was possible.

Faecal pellets and pseudofaeces produced on the A diet had lower erosion thresholds than those produced on the other 2 diets (Fig. 4). Ten percent of the faecal pellets produced on the A diet were eroded at a $u *$ of $0.17 \mathrm{~cm} \mathrm{~s}^{-1}$, and at $0.28 \mathrm{~cm} \mathrm{~s}^{-1}, 90 \%$ of these pellets were removed from the sediment. In comparison, the bed shear velocity required to erode faecal pellets produced on the $\mathrm{N}$ and $\mathrm{S}$ diets was about twice as high for $10 \%$ ( $\mathrm{N}$ diet: $0.36 \mathrm{~cm} \mathrm{~s}^{-1}, \mathrm{~S}$ diet: $0.32 \mathrm{~cm}$ $\mathrm{s}^{-1}$ ) and $90 \%$ erosion ( $\mathrm{N}$ diet: $0.67 \mathrm{~cm} \mathrm{~s}^{-1}$, $\mathrm{S}$ diet: $0.59 \mathrm{~cm} \mathrm{~s}^{-1}$ ). Pseudofaeces generally eroded over a wider range of $u^{*}$, and the differences between the 3 diets were less distinctive compared with faecal pellets. Ten percent of pseudofaeces produced on the A diet eroded at a $u^{*}$ of $0.16 \mathrm{~cm} \mathrm{~s}^{-1}$, and those produced on the $\mathrm{N}$ and S diets at $0.30 \mathrm{~cm} \mathrm{~s}^{-1}$. A $u *$ of $0.44 \mathrm{~cm}$ $\mathrm{s}^{-1}$ eroded $90 \%$ of all pseudofaeces produced on the A diet whereas $0.57 \mathrm{~cm} \mathrm{~s}^{-1}$ was required to remove $90 \%$ of all pseudofaeces produced on the other 2 diets. No consistent pattern was found in the bed shear velocities required to erode biodeposits produced by mussels of the 3 different size classes.

\section{DISCUSSION}

\section{Biodeposit sinking velocities and diet}

Sinking velocities were significantly lower for faecal pellets produced on the
A diet compared with pellets produced on the $\mathrm{N}$ or $\mathrm{S}$ diets due to the high proportion of low-density phytoplankton in the A diet. This was indicated by the dark green colour of these biodeposits as well as their high $\mathrm{OC}$ and chl a content. Because of the similar high inorganic content of the $\mathrm{N}$ and $\mathrm{S}$ diets, faecal pellets produced on these diets had similar compositions, resulting in similar sinking velocities. Pseudofaeces generally settled slower than faecal pellets and rates varied significantly between all 3 diets. Sinking velocities were more variable for pseudofaeces than for faeces, which was most likely due to their more variable shape. Because the A diet was of very high quality, mussels did not have to sort the filtered material before ingestion (Hawkins et al. 1999). Therefore, pseudofaeces contained a high proportion of phytoplankton, indicated by a high OC and chl a content, resulting in low
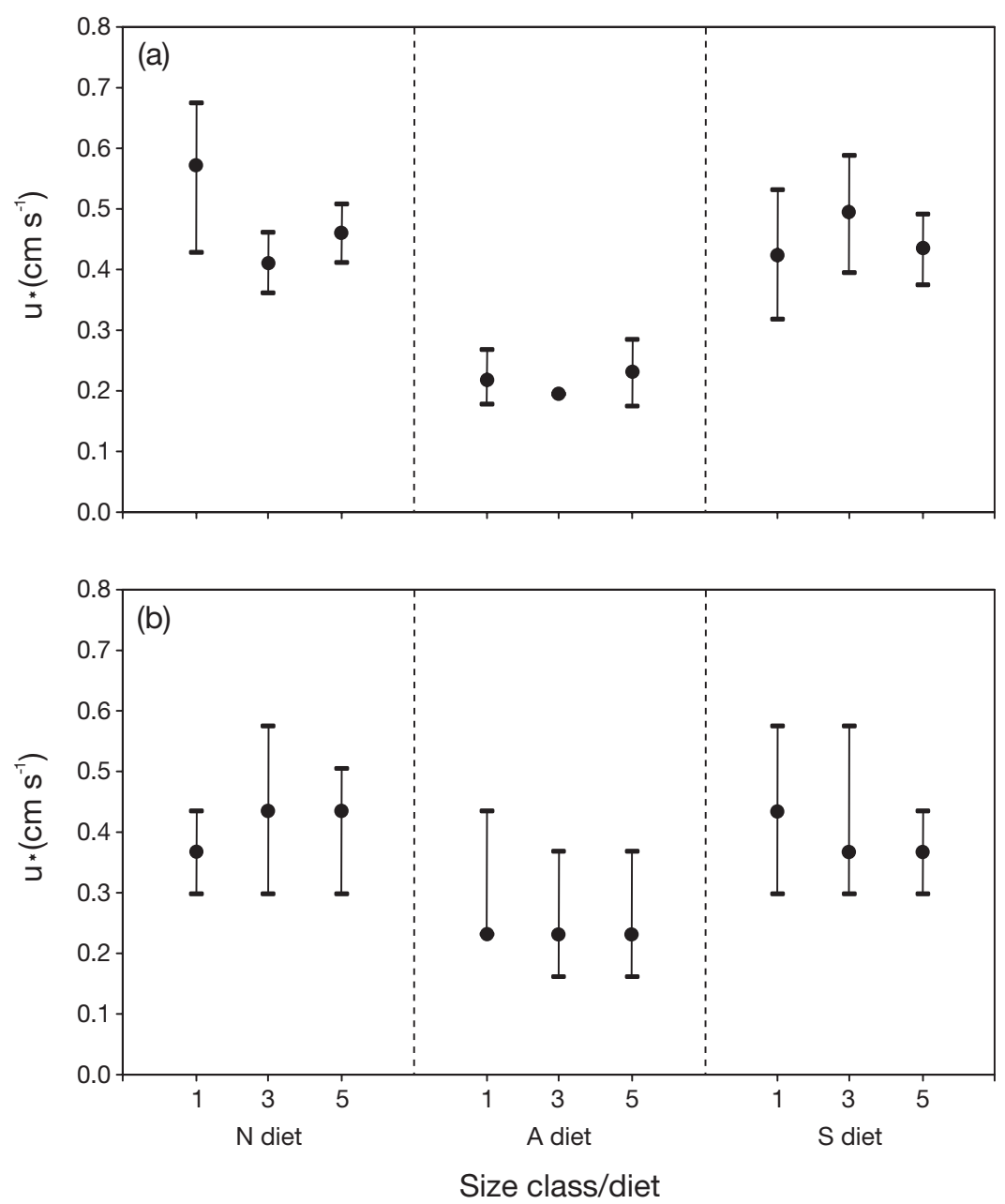

Fig. 4. Perna canaliculus. Bed shear velocities $\left(u^{*}\right)$ required to erode $50 \%(\bullet)$ of (a) individual faecal pellets and (b) pseudofaeces area coverage produced by mussels of size class $1(<40 \mathrm{~mm}), 3(61-80 \mathrm{~mm})$ and $5(>100 \mathrm{~mm})$ fed on the 3 experimental diets (N: natural, A: algae, S: silt). Position of the upper and lower bars (-) represents the bed shear velocity required to erode 90 and $10 \%$ of the biodeposits, respectively. In some instances the bars are covered by the $50 \%$ marker 
sinking velocities. The $\mathrm{S}$ and $\mathrm{N}$ diets both contained heavy silt particles, but their concentration was about $5 \times$ higher in the $\mathrm{S}$ diet, causing denser and heavier pseudofaeces with higher sinking rates. Pseudofaeces produced on the $\mathrm{N}$ diet had a lower OC compared to faeces due to the pre-ingestive selection of filtered material (Ahn 1993, Rueda \& Smaal 2002). In contrast, the OC of pseudofaeces produced on the S diet was slightly elevated, most possibly a result of the high amount of mucus required to package the silt particles (Owen 1966, Prins \& Smaal 1989, Davies \& Hawkins 1998). Generally, there was little difference in composition between faeces and pseudofaeces for the 3 diets, and this probably reflects a high proportion of intestinal faeces relative to glandular faeces. Intestinal faeces are produced when seston concentrations exceed the maximum digestible concentration and are rejected after low levels of digestion in the gut (Widdows et al. 1979).

The sinking velocities of Perna canaliculus biodeposits measured in this study ( 0.1 to $4.5 \mathrm{~cm} \mathrm{~s}^{-1}$ ) fall within the range observed for other aquatic invertebrates. Biodeposit sinking velocities range from approximately $0.02 \mathrm{~cm} \mathrm{~s}^{-1}$ for copepod to $5.94 \mathrm{~cm} \mathrm{~s}^{-1}$ for polychaete faecal pellets (Wotton \& Malmqvist 2001). This variation originates mainly from the differences in organism size and physiology between species, which obviously affects biodeposit size, as well as feeding habits. Aquatic animals living in the water column grazing primarily on algae (such as copepods) and benthic suspension-feeders are likely to produce less-dense biodeposits compared with deposit feeders (such as polychaetes). Similar to this study, lower sinking rates have been measured for biodeposits produced on diets with higher algae concentrations for the horse mussel Atrina zelandica (Miller et al. 2002) and the copepod Acartia tonsa (Butler \& Dam 1994). Higher faecal pellet sinking velocities have been obtained for deposit feeders who are exposed to diets with high proportions of inorganic material (Taghon et al. 1984, Ladle et al. 1987).

No previous studies have examined settling characteristics of pseudofaeces, yet this may represent a significant fraction of the filtered material for suspensionfeeding bivalves in coastal environments. Perna canaliculus produce pseudofaeces at SPM concentrations as low as $3 \mathrm{mg} \mathrm{l}^{-1}$, and at $40 \mathrm{mg} \mathrm{l}^{-1}$ the proportion of filtered material rejected as pseudofaeces is as high as $90 \%$ (Hawkins et al. 1999). The results from this study showed that pseudofaeces have generally lower sinking velocities than faecal pellets. Pseudofaeces are therefore likely to disperse farther from their origin compared with faecal pellets, and their impact on the sediment becomes diffused by being spread over a larger area. In addition, we observed that pseudofaeces were easily destroyed, and in energetic coastal environments turbulence would promote the breakdown of pseudofaeces, reducing their settling velocity and increasing mineralisation in the water column, so that they may never reach the benthos. This could have been the reason why during the first field measurements pseudofaeces were absent in the sediment traps which were placed approximately $4 \mathrm{~m}$ below cultured mussels suspended in the water column. Once some of the material trapped by $P$. canaliculus is rejected as pseudofaeces, the ingestion and faeces production rates remain relatively constant with further increments in SPM concentration (Hawkins et al. 1999). Therefore, above a certain threshold increased SPM concentrations do not inevitably lead to increased sedimentation load. This functional response to high seston concentrations has been demonstrated for a several species, e.g. the blue mussel Mytilus edulis and the Eastern oyster Crassostrea virginica (Griffiths \& Griffiths 1987). However, some bivalves, such as the hard clam Mercenaria mercenaria, show a different response (Tenore \& Dunstan 1973), which has to be taken into account when making biodeposit dispersal estimates.

The results of this study demonstrate that changes in diet composition lead to variations in biodeposit sinking velocity and therefore influence the potential dispersal of biodeposits. The suspended particle concentration in coastal environments is influenced by a wide range of factors, such as storms, currents or seasonal conditions, creating tidal, seasonal and inter-annual fluctuations in the diet available to suspension-feeding bivalves (Berg \& Newell 1987). The impact of mussel biodeposition on the benthos is dependent on the flux to the sediment (amount of biodeposits per unit area and unit time), which, in turn, is a function of production rate and dispersal characteristics as well as biodeposit quality. The biodeposit C:N ratios obtained in this study indicate their high nutritional value compared with sediments which generally have a C:N ratio of 10 or more (Parsons et al. 1977) and fall into the range of previously measured C:N ratios of suspension-feeding bivalves (e.g. Ahn 1993, Miller et al. 2002). Biodeposits produced on the A diet had the lowest C:N ratios, reflecting the high quality of the A diet. Aquaculture leases are preferentially located in highly productive areas to sustain growth and prevent phytoplankton depletion. Therefore, the diet of cultured mussels is likely to contain a higher proportion of chl a compared with mussels living in natural beds, which could result in higher quality biodeposits.

\section{Predicting biodeposit sinking velocity}

Larger mussels produced larger biodeposits, and sinking velocity increased significantly with biodeposit size for faeces and pseudofaeces produced on all 
3 diets. Faecal pellet width is solely determined by mussel morphology and hence mussel size. Mussels produce a string of faecal material which breaks into sections, creating individual pellets (authors' pers. obs.) whose length (and hence also area) depends on mussel orientation and ambient flow and is therefore very variable. The significant effect of mussel size class in the GLMs of biodeposit size and the strong relationship between biodeposit size and sinking velocity indicate that mussel size governs biodeposit dispersal. Bivalve populations are often dominated by a few distinctive cohorts (Loo \& Rosenberg 1989, Strasser et al. 1999, Cole et al. 2000, Witbaard \& Bergman 2003), and if biodeposit dispersal is a function of animal size then biodeposit dispersal could vary considerably with population size structure.

Various efforts have been made to calculate sinking rates from faecal pellet size, density and seawater characteristics using the equations of Komar et al. (1981), Stoke's law and Newton's second law (Komar et al. 1981, Taghon et al. 1984, Ladle et al. 1987, Deibel 1990, Butler \& Dam 1994, Yoon et al. 2001). All equations used to calculate sinking velocities are valid only for certain geometrical shapes (spherical, cylindrical, ellipsoidal, conical or rectangular) and chosen for the best approximation to the shape of the examined faecal pellets. Most comparisons of measured and calculated sinking rates showed inconsistencies, predominantly caused by inaccurate density estimates and/or the deviation of actual pellet shape to the shape assumed for the equation (Taghon et al. 1984, Deibel 1990, Yoon et al. 2001) and good agreements were only found by Komar et al. (1981) for copepod pellets. Since neither faecal pellets nor pseudofaeces produced by Perna canaliculus fit any of the shapes listed above, and no mathematical description of $P$. canaliculus biodeposit shape exists, we were not able to calculate sinking velocities. This demonstrates the importance of empirical relationships of biodeposit size and sinking velocity to estimate dispersal characteristics. However, according to Stoke's law and an equation of Komar that is a semi-empirically derived version of Stokes' law, changes in faecal pellet width cause greater changes in the sinking velocity than changes in faecal pellet length, which is consistent with the strong correlation of faecal pellet width and sinking velocity we found.

\section{Biodeposit erosion}

This study provides a first-order approximation of the bed shear velocities required to initiate the erosion of mussel biodeposits as a function of size and composition. Biodeposits produced on the A diet had lower erosion thresholds than those produced on the other 2 diets, most likely due to their lower density and potentially because of their smoother surface, which reduces the friction between biodeposit and sediment. The similar composition of biodeposits produced on the $\mathrm{N}$ and $\mathrm{S}$ diets resulted in equal erosion thresholds. The range of bed shear stresses over which pseudofaeces eroded was much higher compared with faeces. The erodibility of particles can be affected by their exposure to the flow, which is dependent on particle size, shape and orientation (Jumars \& Nowell 1984). Pseudofaeces had a more variable shape compared with faecal pellets. Furthermore, pseudofaeces partly broke down during movement and at high flow speeds created an almost even layer on the sediment surface, hence reducing their exposure to the flow. No specific pattern was noticeable in the order in which the biodeposits produced by mussels of the 3 size classes eroded off the sediment cores. This was probably due to the trade-off between the higher bed shear velocity required to erode larger and hence heavier particles and the lower bed shear velocity sufficient to initiate the erosion of particles with greater exposure to the flow.

The biodeposit erosion thresholds we measured are similar to the few obtained in previous studies, all of which involved organisms feeding on natural diets. Faecal pellets produced by the deposit feeder Hydrobia ulvae were transported at a $u^{*}$ of 0.10 to $0.44 \mathrm{~cm} \mathrm{~s}^{-1}$ (Austen et al. 1999, Andersen 2001), comparable to those required to erode faecal pellets produced on the algal diet ( 0.17 to $0.28 \mathrm{~cm} \mathrm{~s}^{-1}$ ). Polychaete faecal pellets started to erode at a free-stream velocity of $3 \mathrm{~cm} \mathrm{~s}^{-1}$ measured $5 \mathrm{~cm}$ above the sediment $\left(z_{5}\right)$ and were completely transported at approximately $11 \mathrm{~cm} \mathrm{~s}^{-1}$ (Minoura \& Osaka 1992). The width of these cylindrical pellets was approximately $0.35 \mathrm{~mm}$, similar to faecal pellets produced by mussels of the smallest size class we examined. The flow at $z_{5}$ required to erode $90 \%$ of faecal pellets of the smallest size class ranged from 7 (A diet) to 18 ( $\mathrm{N}$ diet) $\mathrm{cm} \mathrm{s}^{-1}$. Widdows et al. (1998) showed that at current velocities of $20 \mathrm{~cm} \mathrm{~s}^{-1} 10 \mathrm{~cm}$ above the bed $\left(z_{10}\right)$ mussel (Mytilus edulis) pseudofaeces and faeces were resuspended. Because of the water depth in the flume and ADV configuration, we could not directly measure flow velocities at this height; however, by extrapolation of the flow-profile data an estimate could be obtained (flow velocity at $\left.z_{10}\left(\mathrm{~cm} \mathrm{~s}^{-1}\right)=30.8 \times u^{*}-1.1, \mathrm{r}^{2}=0.99\right)$. In this study the flow at $z_{10}$ required to erode $90 \%$ of all biodeposits produced on the $\mathrm{N}$ diet ranged between 12.3 and $19.6 \mathrm{~cm} \mathrm{~s}^{-1}$, which is very similar to the flow speed measured by Widdows et al. (1998).

The erosion thresholds obtained in this study should only be used as an approximation since they were 
measured under idealistic laboratory conditions with a smooth sediment surface devoid of macrofauna or other obstacles. In natural sediments faecal material reduces sediment stability (e.g. Andersen et al. 2002), but because in this study biodeposits were placed on top of the experimental sediments prior to the measurements, this effect was not observed. Suspensionfeeding bivalves alter their physical habitat, bed roughness and water flow over the seabed (Frechette et al. 1989, Green et al. 1998) through bioturbation, surface tracking and the production of faecal pellet mounds as well as by their own presence (Willows et al. 1998, Widdows et al. 2000, Andersen 2001, Andersen et al. 2002). Because of these factors, comparisons of erosion thresholds measured in different environments should be done with care. To attain more realistic erosion thresholds in the laboratory, intact sediment cores should be used to simulate the effect of bioturbating macrofauna and the presence of other animals and structures. Experimental set-ups should also consider realistic bottom topographies which significantly alter the flow dynamics above the sediment bed.

In this study we examined freshly egested biodeposits which have not been exposed to any further modification. However, biodeposits provide an important food supply for the benthos and may be eaten and hence repackaged by many marine animals (Johannes \& Satomi 1966, Frankenberg \& Smith 1967, Tenore \& Dunstan 1973, Wotton et al. 1998) including the species that produced them (Newell 1965). Furthermore, biodeposits are mineralised rapidly with peak activity in the first $3 \mathrm{~d}$ of degradation followed by a decline to initial levels after 8 to 30 d (Turner \& Ferrante 1979, Stuart et al. 1982, Grenz et al. 1990, Fabiano et al. 1994). The significance of biodeposit modification is dependent on the composition of the benthos. Repackaging and ageing alters biodeposit density, composition and sinking rates (Gonzales \& Biddanda 1990, Fabiano et al. 1994, Yoon et al. 1996) and would likely affect erosion thresholds. The implications of biodeposit modification by the benthos should therefore be examined to obtain a more comprehensive understanding of biodeposit redistribution.

\section{Estimated dispersal distances of mussel biodeposits}

Perna canaliculus naturally forms dense beds of up to $100 \mathrm{~m}^{-2}$ (Jeffs et al. 1999) which are predominantly found subtidally or in the low intertidal. In suspended cultures, mussels are attached to dropper lines hanging off floating longlines. To examine the spatial extent of biodeposit dispersal from mussel farms we calculated the approximate initial dispersal distance from the commercial farm described above as a function of biodeposit sinking velocity, water depth and current velocity. Based on the mean depth of the water underneath the dropper lines $(6 \mathrm{~m})$, the mean current velocity measured $1 \mathrm{~m}$ above the sediment $\left(12.8 \mathrm{~cm} \mathrm{~s}^{-1}\right)$ and the average sinking velocities of biodeposits produced on the $\mathrm{N}$ diet, the initial contact with the sediment would be 31 (faecal pellets) and $62 \mathrm{~m}$ (pseudofaeces) away from the release point. Applying the lower sinking rates of biodeposits produced on the algae dominated diet resulted in initial dispersal distances of 124 (faecal pellets) and $181 \mathrm{~m}$ (pseudofaeces). To estimate the significance of secondary dispersal via erosion at the farm, we transformed the bed shear velocities measured in this study to equivalent flow speeds $1 \mathrm{~m}$ above the sediment bed (Muschenheim et al. 1986). We found that over a range of 5.1 to $21.4 \mathrm{~cm} \mathrm{~s}^{-1}$ all biodeposits would be eroded. The mean current velocity at the mussel farm falls within this range and hence could initiate the erosion of a large fraction of the material. The observed maximum current speed of $33 \mathrm{~cm} \mathrm{~s}^{-1}$ would be strong enough to completely erode all material.

These estimates show that the initial dispersal of biodeposits from the farm is not far but that it could increase significantly during algae blooms. The initial dispersal of biodeposits from natural mussel beds would be lower since biodeposits are released into the boundary layer and therefore only exposed to lower current velocities. Pseudofaeces initially disperse further than faeces due to their lower sinking velocities. Depending on the hydrodynamic conditions, secondary dispersal potentially plays a more important role in the dispersal of biodeposits from mussel farms than initial dispersal and almost certainly serves as the major means of transport of biodeposits from natural mussel beds. Because pseudofaeces partly break down during erosion, they will most likely create a layer of organic material in the vicinity of their initial point of contact with the sediment.

We have shown that biodeposit dispersal depends on the available diet and mussel size, and we conclude that it could vary considerably as a function of site and environmental conditions. Further research should address the effects of biodeposit repackaging and age on dispersal characteristics. Due to the commonly shallow habitats of mussels and their fast biodeposit sinking rates, age has probably only a minor effect on the initial dispersal; however, because of the high potential for redistribution and modification by the benthos, it could significantly alter further dispersal.

Acknowledgements. We thank D. Bell for help in the field, D. and M. Aislabe for access to their mussel farm and Dr. S. Nodder for providing sediment traps. We also thank 
Dr. A. Zwart for statistical advice, and Dr. C. Lundquist and 3 anonymous reviewers for suggestions on an earlier version of this manuscript. A University of Waikato postgraduate scholarship funded H.G.

\section{LITERATURE CITED}

Ahn IY (1993) Enhanced particle flux through the biodeposition by the Antarctic suspension-feeding Bivalve Laternula elliptica in Marian Cove, King George Island. J Exp Mar Biol Ecol 171:75-90

Andersen TJ (2001) Seasonal variation in erodibility of two temperate, microtidal mudflats. Estuar Coast Shelf Sci 53: $1-12$

Andersen TJ, Jensen KT, Lund-Hansen L, Mouritsen KN, Pejrup M (2002) Enhanced erodibility of fine-grained marine sediments by Hydrobia ulvae. J Sea Res 48(1):51-58

Arar EJ, Collins GB (1997) In vitro determination of chlorophyll a and pheophytin a in marine and freshwater algae by fluorescence. National Exposure Research Laboratory, Office of Research and Development, US Environmental Protection Agency, Washington, DC

Asmus H, Asmus RM (1992) Benthic-pelagic flux rates on mussel beds. Helgol Meeresunters 46:341-361

Austen I, Andersen TJ, Edelvang K (1999) The influence of benthic diatoms and invertebrates on the erodibility of an intertidal mudflat, the Danish Wadden Sea. Estuar Coast Shelf Sci 49:99-111

Bayne BL (1993) Feeding physiology of bivalves: time-dependence and compensation for changes in food availability. In: Dame RF (ed) Bivalve filter feeders in estuarine and coastal ecosystem processes. Springer-Verlag, Berlin, p 1-24

Berg JA, Newell RIE (1987) The role of physical factors in regulating temporal and spatial variations in seston. In: Neilson B, Brubker J, Kuo A (eds) Estuarine circulation. Humana Press, Clifton, NJ, p 235-253

Bloesch J, Burns NM (1980) A critical review of sediment trap technique. Schweiz Z Hydrol 42(1):15-55

Butler M, Dam HG (1994) Production rates and characteristics of fecal pellets of the copepod Acartia tonsa under simulated phytoplankton bloom conditions: implications for vertical fluxes. Mar Ecol Prog Ser 114:81-91

Cole RG, Hull PJ, Healy TR (2000) Assemblage structure, spatial patterns, recruitment, and post-settlement mortality of subtidal bivalve molluscs in a large harbour in north-eastern New Zealand. N Z J Mar Freshw Res 34:317-329

Dahlbaeck B, Gunnarsson LAH (1981) Sedimentation and sulphate reduction under a mussel culture. Mar Biol 63: 269-275

Dame RF (1993) The role of bivalve filter feeder material fluxes in estuarine ecosystems. In: Dame RF (ed) Bivalve filter feeders in estuarine and coastal ecosystem processes. Springer-Verlag, Berlin, p 245-269

Davies MS, Hawkins SJ (1998) Mucus from marine molluscs. Adv Mar Biol 34:1-71

Deibel D (1990) Still-water sinking velocity of fecal material from the pelagic tunicate Dolioletta gegenbauri. Mar Ecol Prog Ser 62:55-60

Fabiano M, Danovaro R, Olivari E, Misic C (1994) Decomposition of faecal matter and somatic tissue of Mytilus galloprovincialis: changes in organic matter composition and microbial succession. Mar Biol 119:375-384

Falconer RA, Owens PH (1990) Numerical modelling of suspended sediment fluxes in estuarine waters. Estuar Coast Shelf Sci 31:745-762

Fegley SR, MacDonald BA, Jacobsen TR (1992) Short-term vari- ation in the quantity and quality of seston available to benthic suspension feeders. Estuar Coast Shelf Sci 34:393-412

Finelli CM, Hart DD, Fonseca DM (1999) Evaluating the spatial resolution of an acoustic Doppler velocimeter and the consequences for measuring near-bed flows. Limnol Oceanogr 44(7):1793-1801

Frankenberg D, Smith KL (1967) Coprophagy in marine animals. Limnol Oceanogr 12:443-450

Frechette M, Butman CA, Geyer WR (1989) The importance of boundary-layer flows in supplying phytoplankton to the benthic suspension feeder, Mytilus edulis. Limnol Oceanogr 34(1):19-36

Gonzales H, Biddanda B (1990) Microbial transformation of metazoan (Idotea granulosa) faeces. Mar Biol 106:285-295

Graf G, Rosenberg R (1997) Bioresuspension and biodeposition: a review. J Mar Syst 11:269-278

Grall J, Chauvaud L (2002) Marine eutrophication and benthos: the need for new approaches and concepts. Global Change Biol 8(9):813-830

Green MO, Hewitt JE, Thrush SF (1998) Seabed drag coefficient over natural beds of horse mussels (Atrina zelandica). J Mar Res 56(3):613-637

Greenway JPC (1969) Survey of mussels (mollusca: lamellibranchia) in the Firth of Thames, 1961-67. N Z J Mar Freshw Res 3:304-317

Grenz C, Hermin MN, Baudinet D, Daumas R (1990) In situ biochemical and bacterial variation of sediments enriched with mussel biodeposits. Hydrobiologia 207:153-160

Griffiths CL, Griffiths RJ (1987) Bivalvia. In: Pandian TJ, Vernberg FJ (eds) Animal energetics. Academic Press, New York, p 1-88

Hargrave BT (1973) Coupling carbon flow through some pelagic and benthic communities. J Fish Res Board Can 30:1317-1326

Haven DS, Morales-Alamo R (1968) Occurence and transport of faecal pellets in suspension in a tidal estuary. Sediment Geol 2:125-140

Hawkins AJS, Smith RFM, Bayne BL, Heral M (1996) Novel observations underlying the fast growth of suspensionfeeding shellfish in turbid environments: Mytilus edulis. Mar Ecol Prog Ser 131:179-190

Hawkins AJS, Smith RFM, Tan SH, Yasin ZB (1998) Suspension-feeding behaviour in tropical bivalve molluscs: Perna viridis, Crassostrea belcheri, Crassostrea iradelei, Saccostrea cucculata and Pinctada margarifera. Mar Ecol Prog Ser 166:173-185

Hawkins AJS, James MR, Hickman RW, Hatton S, Weatherhead M (1999) Modelling of suspension-feeding and growth in the green-lipped mussel Perna canaliculus exposed to natural and experimental variations of seston availability in the Marlborough Sounds, New Zealand. Mar Ecol Prog Ser 191:217-232

Henderson A, Gamito S, Karakassis I, Pederson P, Smaal A (2001) Use of hydrodynamic and benthic models for managing environmental impacts of marine aquaculture. J Appl Ichthyol 17(4):163-172

Jeffs AG, Holland RC, Hooker SH, Hayden BJ (1999) Overview and bibliography of research on the Greenshell mussel, Perna canaliculus, from New Zealand waters. J Shellfish Res 18(2):347-360

Johannes RE, Satomi M (1966) Composition and nutritive value of fecal pellets of a marine crustacean. Limnol Oceanogr 11:191-197

Jumars PA, Nowell ARM (1984) Effects of benthos on sediment transport: difficulties with functional grouping. Cont Shelf Res 3(2):115-130

Kaspar HF, Gillespie PA, Boyer IC, MacKenzie AL (1985) 
Effects of mussel aquaculture on the nitrogen cycle and benthic communities in Kenepuru Sound, Marlborough Sounds, New Zealand. Mar Biol 85:127-136

Kautsky N, Evans S (1987) Role of biodeposition by Mytilus edulis in the circulation of matter and nutrients in a Baltic coastal ecosystem. Mar Ecol Prog Ser 38:201-212

Komar PD, Morse AP, Small LF, Fowler SW (1981) An analysis of sinking rates of natural copepod and euphausiid fecal pellets. Limnol Oceanogr 26(1):172-180

Ladle M, Welton JS, Bell MC (1987) Sinking rates and physical properties of faecal pellets of freshwater invertebrates of the genera Simulium and Gammarus. Arch Hydrobiol 108(3):411-424

La Rosa T, Mirto S, Favaloro E, Savonna B, Sara G, Danovaro R, Mazzolla A (2002) Impact on the water column biogeochemistry of a Mediterranean mussel and fish farm. Water Res 36:713-721

Loo LO, Rosenberg R (1989) Bivalve suspension-feeding dynamics and benthic-pelagic coupling in an eutrophicated marine bay. J Exp Mar Biol Ecol 130:253-276

McCall PL (1979) The effects of deposit feeding oligochaetes on particle size and settling velocity of Lake Erie sediments. J Sediment Petrol 49:813-818

Miller DC, Norkko A, Pilditch CA (2002) Influence of diet on dispersal of horse mussel Atrina zelandica biodeposits. Mar Ecol Prog Ser 242:153-167

Minoura K, Osaka Y (1992) Sediments and sedimentary processes in Mutsu Bay, Japan: pelletization as the most important mode in depositing argillaceous sediments. Mar Geol 103:487-502

Mirto S, La Rosa T, Danovaro R, Mazzola A (2000) Microbial and meiofaunal response to intensive mussel-farm biodeposition in coastal sediments of the Western Mediterranean. Mar Pollut Bull 40(3):244-252

Morton J, Miller M (1973) The New Zealand sea shore, 2nd edn. William Collins \& Sons, Glasgow

Muschenheim DK, Grant J, Mills EL (1986) Flumes for benthic ecologists: theory, construction and practice. Mar Ecol Prog Ser 28:185-196

Newell R (1965) The role of detritus in the nutrition of two marine deposit feeders, the prosobranch Hydrobia ulvae and the bivalve Macoma balthica. Proc Zool Soc Lond 144(1):25-45

Newell RIE, Cornwell JC, Owens MS (2002) Influence of simulated bivalve biodeposition and microphytobenthos on sediment nitrogen dynamics: a laboratory study. Limnol Oceanogr 47(5):1367-1379

Nixon SW (1981) Remineralization and nutrient cycling in coastal marine ecosystems. In: Neilson BJ, Cronin LE (eds) Estuaries and nutrients. Humana Press, Clifton, NJ, p 111-138

Norkko A, Hewitt JE, Thrush SF, Funnell GA (2001) Benthicpelagic coupling and suspension-feeding bivalves: linking site-specific sediment flux and biodeposition to benthic community structure. Limnol Oceanogr 46(8):2067-2072

Nowell ARM, Jumars PA, Eckman JE (1981) Effects of biological activity on the entrainment of marine sediments. Mar Geol 42:133-153

Owen G (1966) Digestion. In: Wilbur KM, Yonge CM (eds) Physiology of mollusca II. Academic Press, New York, p 53-96

Parsons TR, Takahashi M, Hargrave B (1977) Biological oceanographic processes, 2nd edn. Pergamon Press, Oxford

Parsons TR, Takahashi M, Hargrave B (1984) Biological oceanographic processes, 3rd edn. Pergamon Press, Oxford, p 55-60

Prins TC, Smaal AC (1989) Carbon and nitrogen budgets of the mussel Mytilus edulis L. and the cockle Cerastoderma edule (L.) in relation to food quality. In: Ros JD (ed) Topics in marine biology. Sci Mar 53(2-3):477-482

Roditi HA, Strayer DL, Findlay SEG (1997) Characteristics of zebra mussel (Dreissena polymorpha) biodeposits in a tidal freshwater estuary. Arch Hydrobiol 140(2):207-219

Rueda JL, Smaal AC (2002) Physiological response of Spisula Subtruncata (Da Costa, 1778) to different seston quantity and quality. Hydrobiologia 475(1):505-511

Smaal AC, Prins TC (1993) The uptake of organic matter and the release of inorganic nutrients by bivalve suspension feeder beds. In: Dame RF (ed) Bivalve filter feeders in estuarine and coastal ecosystem processes. SpringerVerlag, Berlin, p 271-298

Sobral P, Widdows J (2000) Effects of increasing current velocity, turbidity and particle-size selection on the feeding activity and scope for growth of Ruditapes decussatus from Ria Formosa, southern Portugal. J Exp Mar Biol Ecol 245:111-125

Strasser M, Walensky M, Reise K (1999) Juvenile-adult distribution of the bivalve Mya arenaria on intertidal flats in the Wadden Sea: why are there so few year classes? Helgol Mar Res 53(1):45-55

Stuart V, Newell RC, Lucas MI (1982) Conversion of kelp debris and faecal material from the mussel Aulacomya ater by marine micro-organisms. Mar Ecol Prog Ser 7:47-57

Taghon GL, Nowell ARM, Jumars PA (1984) Transport and breakdown of fecal pellets: biological and sedimentological consequences. Limnol Oceanogr 29(1):64-72

Tenore KR, Dunstan WM (1973) Comparison of feeding and biodepositon of three bivalves at different food levels. Mar Biol 21:190-195

Tenore KR, Boyer LF, Cal RM, Corral J and 15 others (1982) Coastal upwelling in the Rias Bajas, NW Spain: contrasting the benthic regimes of the Rias de Arosa and de Muros. J Mar Res 40(3):701-772

Turner JT, Ferrante JG (1979) Zooplankton fecal pellets in aquatic ecosystems. BioScience 29(11):670-677

Widdows J, Fieth P, Worrall CM (1979) Relationships between seston, available food and feeding activity in the common mussel Mytilus edulis. Mar Biol 50:195-207

Widdows J, Brinsley MD, Salkeld PN, Elliott M (1998) Use of annular flumes to determine the influence of current velocity and bivalves on material flux at the sedimentwater interface. Estuaries 21(4):552-559

Widdows J, Brinsley MD, Salkeld PN, Lucas CH (2000) Influence of biota on spatial and temporal variation in sediment erodability and material flux on a tidal flat (Westershelde, The Netherlands). Mar Ecol Prog Ser 194:23-37

Willows RI, Widdows J, Wood RG (1998) Influence of an infaunal bivalve on the erosion of an intertidal cohesive sediment: a flume and modeling study. Limnol Oceanogr 43(6):1332-1343

Witbaard R, Bergman MJN (2003) The distribution and population structure of the bivalve Arctica islandica L. in the North Sea: what possible factors are involved? J Sea Res 50(1):11-25

Wotton RS, Malmqvist B (2001) Feces in aquatic ecosystems. BioScience 51(7):537-544

Wotton RS, Malmqvist B, Muotka T, Larsson K (1998) Fecal pellets from a dense aggregation of suspension-feeders in a stream: an example of ecosystem engineering. Limnol Oceanogr 43(4):719-725

Yoon WD, Kim SK, Han KN (2001) Morphology and sinking velocities of fecal pellets of copepod, molluscan, eupausiid, and salp taxa in the northeastern tropical Atlantic. Mar Biol 139:923-928 